\title{
Sprawozdanie z seminarium European Holocaust Research Infrastructure „Nowoczesna dyplomatyka akt dotyczących Holokaustu” w Bundesarchiv w Berlinie
}

W dniach 22-30 sierpnia 2016 r. wzięłam udział w seminarium poświęconym dyplomatyce akt dotyczących Holokaustu,w Bundesarchiv w Berlinie. Seminarium zostało zorganizowane ze środków European Holocaust Research Infrastructure (EHRI).

Seminarium było podzielone na sześć części, w których udział był obowiązkowy: 2 moduły z zakresu nauki o administracji, 3 moduły poświęcone dyplomatyce, 6 modułów dotyczących źródłoznawstwa, 7 modułów o tematyce związanej z Bundesarchiv, 3 wykłady eksternistyczne i 5 wycieczek. Zajęcia odbywały się w formie wykładów, często uzupełnionych ciekawymi prezentacjami, a także w formie prac warsztatowych, podczas których uczestnicy seminarium pracowali samodzielnie. Ich zadaniem było także przedstawienie krótkiej prezentacji dotyczącej zasobu archiwum instytucji, którą reprezentowali oraz własnych obszarów badawczych.

W ramach modułu z zakresu nauki o administracji była możliwość wysłuchania dwuczęściowego wykładu Anette Meiburg „Wprowadzenie do historii administracji niemieckiej".

Moduł dotyczący dyplomatyki obejmował dwa wykłady: Nicolai M. Zimmermanna i dr. Tobiasa Herrmanna, poświęcone metodologii klasyfikacji i etapom narastania XX-wiecznej dokumentacji akt spraw oraz obiegowi dokumentacji, a także pomocom kancelaryjnym we współczesnej kancelarii, na przykładzie materiałów archiwalnych niemieckich urzędów centralnych funkcjonujących w czasach III Rzeszy. Bardzo ciekawe i szczególnie wartościowe były praktyczne zajęcia warsztatowe z zakresu dyplomatyki. Uczestnicy pracowali w małych grupach (2-4-osobowych), mając do dyspozycji wydruki skanów dokumentów odtwarzających przebieg danej sprawy. Mogli się także posiłkować oryginałami akt oraz świetnie zachowanymi pomocami kancelaryjnymi, w formie np. wykazu paraf, instrukcji kancelaryjnej, czy też strukturalnego wykazu akt. Należało odtworzyć sposób przebiegu i załatwienia sprawy, rozszyfrowując wszystkie dekretacje oraz punkty zatrzymania, łącznie z nazwiskami konkretnych referentów odpowiedzialnych merytorycznie za realizację sprawy.

W ramach zajęć ze źródłoznawstwa wysłuchałam wykładu Jany Blumberg oraz Heinza Fehlauera poświęconego dokumentacji zawierającej dane osobowe i prawnym aspektom jej udostępniania oraz praktyce stosowanej w Bundesarchiv. W tematyce tego modułu były także następujące prelekcje: N. M. Zimmermanna oraz dr. T. Herrmanna, dotycząca materiałów archiwalnych i analizy obiegu dokumentacji w urzędach ministerialnych III Rzeszy; dr. T. Herrmanna i Olgi Golety poświęcona ściganiu przestępstw zbrodniarzy nazistowskich; dr. Stefana Hördlera i dr. Christopha Kreutzmüllera dotycząca krytycznej analizy materiałów archiwalnych fotograficznych z KL Auchwitz oraz dr. Thomasa Menzela, który zaprezentował Militärarchiv oraz materiały archiwalne z zakresu wojskowości stanowiące 
źródła do badań nad Holokaustem. W ramach części poświęconej źródłoznawstwu odbyły się także warsztaty w archiwum Jüdisches Museum Berlin, gdzie zaprezentowano materiały archiwalne, które trafiły do ww. placówki, najczęściej jako spuścizna rodzin żydowskich mieszkających przed wojną na terenie III Rzeszy.

Dużo czasu poświęcono także samej organizacji i zasobowi Bundesarchiv. W tej części seminarium wysłuchałam wykładów m.in.: dr. Waltera Naasnera, który wprowadził słuchaczy w tematykę materiałów archiwalnych przechowywanych w zasobie Oddziału $\mathrm{R}$ (Deutsches Reich), istotnych z punktu widzenia badań nad Holokaustem; N.M. Zimmermanna przedstawiającego założenia projektu „Dokumentation der Judenverfolgung”, którego efektem jest baza danych Gedenkbuch für die Opfer der NS-Judenverfolgung (dostępna na stronie internetowej www.bundesarchiv.de); dr. Petera Gohle traktującego o zasobie Centrali Badania Zbrodni Narodowosocjalistycznych w Ludwigsburgu; dr. Olivera Sandera prezentującego Bildarchiv w Koblenz oraz Babette Heusterberg przedstawiającej Filmarchiv w Berlinie. Moduł zakończono wykładem Matthiasa Meissnera, który zapoznał uczestników z projektem portalu informacyjnego, poświęconego ofiarom eutanazji i pracy przymusowej („Praca przymusowa na rzecz III Rzeszy” - www.zwangarbeit.eu, „Inwentarz źródeł do historii zbrodni eutanazji 1939-1945" - www.bundesarchiv.de). Marcus Benhaimi oprowadził uczestników po Bundesarchiv w Berlinie.

Wykłady eksternistyczne to m.in. prelekcje: dr. Akima Jaha o zasobie Międzynarodowej Służby Śledczej (International Tracing Service) w Bad Arolsen i deportacjach do obozów zagłady na Wschodzie; Gilesa Bennetta traktująca o projekcie i portalu EHRI oraz dr hab. Susanne Heim dotycząca przedsięwzięcia wydawniczego „Prześladowanie i zagłada Żydów europejskich przez narodowosocjalistyczne Niemcy 1933-1945”.

W ramach wycieczek uczestnicy seminarium mieli możliwość zwiedzenia Tajnego Archiwum Państwowego Fundacji Pruskiego Dziedzictwa Kulturalnego w Berlinie (Geheimes Staatsarchiv Preußischer Kulturbesitz) pod przewodnictwem dyrektora - prof. Jürgena Kloosterhuisa, Domu Konferencji w Wannsee, gdzie zapoznali się z wystawą poświeconą ww. wydarzeniu oraz z zasobem prowadzonej tam biblioteki. Szczególne zainteresowanie wzbudziły elementarze i książki dla dzieci, wydane w latach 30. XX w., zawierające treści antysemickie. Zwiedzono także Muzeum Żydowskie w Berlinie, wystawę w muzeum Pomnik Pomordowanych Żydów Europy oraz wystawę „Topografia Terroru”.

Dodatkowo w programie seminarium znalazły się nieobowiązkowe oferty, np. spacer po dzielnicy Lichterfelde śladami kamieni pamięci (Stolperstein), spacer po dzielnicy Wannsee, zwiedzanie synagogi, Noc Muzeów, wizyta w teatrze, czy też projekcja filmu, pt. „Niedokończony film”, dotyczącego getta warszawskiego.

Podsumowując udział w seminarium, należy stwierdzić, że było przygotowane na wysokim poziomie merytorycznym i organizacyjnym, a bogaty i różnorodny program zapewnił uczestnikom możliwość poszerzenia wiedzy i zdobycia wielu umiejętności zawodowych.

Agnieszka Filipek Archiwum Narodowe w Krakowie 